\section{Estudo \\ CoDebate}

em CAStão

Plamejamento
Revista Estudo \& Debate, Lajeado, v. 25, n. 3, 2018. ISSN 1983-036X

DOI: http://dx.doi.org/10.22410/issn.1983-036X.v25i3a2018.1724

\title{
GESTÃO DE RESÍDUOS DA CONSTRUÇÃO CIVIL NO MUNICÍPIO DE PRIMAVERA DO LESTE-MT
}

\author{
Jéssica Karina Debacker ${ }^{1}$, Greyce Bernardes de Mello Rezende ${ }^{2}$
}

\begin{abstract}
Resumo: O descarte adequado dos resíduos da construção civil (RCC) é de suma importância para evitar ou diminuir os impactos causados ao meio ambiente. Este estudo procurou investigar a atual gestáo dos RCC no município de Primavera do Leste-MT, e foi averiguado se ela condiz com o que a Resolução CONAMA no 307/2002 designa. A metodologia empregada classifica-se como exploratória e descritiva. Dessa forma, foram apresentadas pesquisas bibliográficas que conceituam construção civil e desenvolvimento sustentável; definição e classificação dos RCC; redução, reutilização e reciclagem e gestão de RCC. Levantou-se informaçóes a respeito do gerenciamento realizado pelos geradores de RCC e sobre o transporte e o descarte feito pelos coletores. Para tanto, foi feito diagnóstico em cinco obras de quatro construtoras. Também foi realizada a estimativa de geração de RCC diária per capita, para compará-la com a média nacional, que é de $0,5 \mathrm{t} / \mathrm{habitante} / \mathrm{ano}$, sendo que o valor obtido através dos cálculos realizados foi de 0,75 t/habitante/ano. Também foram observados pontos de descarte irregulares e uso inadequado dos EcoPontos espalhados pela cidade. Por meio deste estudo foi possível observar que a gestáo aplicada ao município de Primavera do Leste, atualmente, náo condiz com o que a resolução supracitada estabelece. Diante disso, foram propostas sugestóes para melhorar a gestáo dos RCC no município, visando adequá-la à resolução.
\end{abstract}

Palavras-chave: Resíduos da construção civil; Gestão ambiental; Disposição de resíduos.

\section{MANAGEMENT OF CIVIL CONSTRUCTION WASTE IN THE MUNICIPALITY OF PRIMAVERA DO LESTE-MT}

\begin{abstract}
The adequate disposal of civil construction waste (CCW) is important to avoid or diminish the impacts to the environment. This study aimed to investigate the current handling of CCW at Primavera do Leste city, in Mato Grosso state, Brazil, and, in addition, it was verified if such handling was being done accordingly to what Brazil's National Council of Environment (CONAMA) Resolution 307/2002 says. The methodology used is classified as exploratory and descriptive. This way, bibliographical researches which conceptualizes civil construction and sustainable development; definition and types of CCW; reduction, reuse and recycle and $\mathrm{CCW}$ handling. It was gathered information related to the handling made by the CCW producer and its
\end{abstract}

1 Graduada em Engenharia Civil pela UFMT, e graduanda em Arquitetura e Urbanismo pela UFMT, jessica-kd@hotmail.com.

2 Arquiteta e Urbanista, Profa. Adjunto II - UFMT/ICET/CUA- Engenharia Civil, especialista em Gestão e Gerenciamento de Obras, Mestra em Engenharia Civil, Doutora em Recursos Naturais, greycebernardes@yahoo.com.br. 
transportation and disposal done by the collectors. For such, a diagnostic was done in five construction sites of four construction companies. It was also done the estimative of CCW generation per capita, in order to compare it to the national average, which is $0,5 \mathrm{t} /$ inhabitant/year, being the calculated figure $0,75 \mathrm{t} /$ inhabitant/ year. It was also observed some irregular disposal places and the incorrect use of EcoPontos throughout the city. By this study, it was possible to observe that the handling applied to the city of Primavera do Leste, at the present day, is not being done accordingly to the foregoing CONAMA's Resolution. Therefore, suggestions were made to improve the CCW handling in Primavera do Leste city, aiming for it to match CONAMA's Resolution.

Keywords: Civil construction waste; Environmental management; Waste disposal.

\section{1- Introdução}

O atual modelo de produção, seja de bens duráveis (pontes, edifícios), ou nãoduráveis (embalagens descartáveis), implica na geração de resíduos. A matéria-prima, na maioria das vezes, advém de recursos não-renováveis extraídos da natureza. $\mathrm{O}$ aumento populacional e o avanço tecnológico causaram um crescimento exagerado na geraçáo de resíduos, provocando o seu acúmulo, o que ocasiona desde problemas no saneamento público e contaminação ambiental até problemas no âmbito social.

Ademais, o presente estudo define conceitos a respeito da gestão dos RCC, expóe a atual gestão dos resíduos aplicada em Primavera do Leste, estima a geração de resíduos per capita, possibilitando compará-la com a média nacional e com a geração estimada de municípios adjacentes, e demonstra como deve ser feito o gerenciamento dos mesmos pelos geradores e pelo município em questáo, evidenciando os problemas encontrados e suas possíveis soluções.

O município de Primavera do Leste é a quinta maior economia do estado de Mato Grosso (ALVES, 2013). O setor imobiliário tem grande destaque no município, que é muito conhecido pela beleza arquitetônica de suas edificaçóes, consequentemente o município apresenta elevado número de construçóes. Isso influencia diretamente no volume de resíduos da construção civil (RCC) produzido. Dessa forma, realizou-se um estudo sobre a atual situação da gestão de RCC no município por conta de sua importância econômica e pelo seu expressivo mercado imobiliário.

\section{2- Referencial teórico}

\section{1- Construção civil e desenvolvimento sustentável}

A construção civil é considerada um setor-chave para o crescimento econômico, sendo responsável por geração de renda e de emprego, impactando diretamente a economia brasileira; e, além disso, possui importância indireta para o desenvolvimento (TEIXEIRA; CARVALHO, 2005).

A indústria da construção, portanto, possui relevância estratégica para o desenvolvimento de diversas atividades econômicas e produz infraestrutura para as mesmas. $\mathrm{Na}$ concepção de Rigolon (1996, p. 2): “O investimento em infraestrutura promove o crescimento econômico porque aumenta o retorno dos insumos privados (capital e trabalho) e incentiva o investimento e o emprego". 
Veiga (2005) pressupóe que o desenvolvimento não se limita aos aspectos sociais e econômicos, mas envolve a cultura e a interaçáo entre sociedade e biosfera, se tratando de uma co-evoluçáo entre elas. $\mathrm{O}$ autor reitera que sustentabilidade depende do posicionamento das civilizaçôes humanas em fazer bom uso da natureza.

De acordo com o Relatório Brundtland (1987, p. 9): “O desenvolvimento sustentável é aquele que atende as necessidades do presente sem comprometer as possibilidades de as geraçôes futuras atenderem suas próprias necessidades".

Desta forma, o desenvolvimento sustentável pondera a exploraçáo sensata dos recursos naturais, atendendo as necessidades e o bem-estar da sociedade atual sem comprometer a sobrevivência das geraçóes futuras, visando a perpetuação da preservação ambiental (SEABRA et al., 2013).

A concepção de desenvolvimento sustentável estabelece a necessidade de uma harmonia entre seres humanos e entre a humanidade e a natureza. $O$ verdadeiro desenvolvimento integra os interesses sociais, econômicos e as condiçóes e limitaçóes que a natureza determina (CAMARGO, 2003).

Além disso, o desenvolvimento sustentável considera a capacidade da sociedade em se manter, a médio e longo prazo, melhorando o crescimento econômico e, consequentemente, o padrão de vida da população; sendo imprescindível usufruir dos recursos naturais de maneira eficiente (LIBRELOTTO, 2008).

Outrossim, meio ambiente e desenvolvimento estâo intimamente ligados, pois, o desenvolvimento não acontece se a fonte de recursos naturais se esgota, da mesma forma que o meio ambiente não pode ser preservado se o crescimento náo considera as consequências da destruição ambiental. Logo, os processos decisórios da economia devem considerar os problemas ecológicos (RAMPAZZO, 2002 apud KARPINSKI et al., 2009).

Em síntese, o desenvolvimento sustentável envolve interesses econômicos, ambientais, culturais, políticos, legais, sociais e técnicos (KARPINSKI et al., 2009). Esses interesses podem ser agrupados em três dimensóes, que sáo demonstradas na Figura 1. 
Figura 1 - Componentes do desenvolvimento sustentável

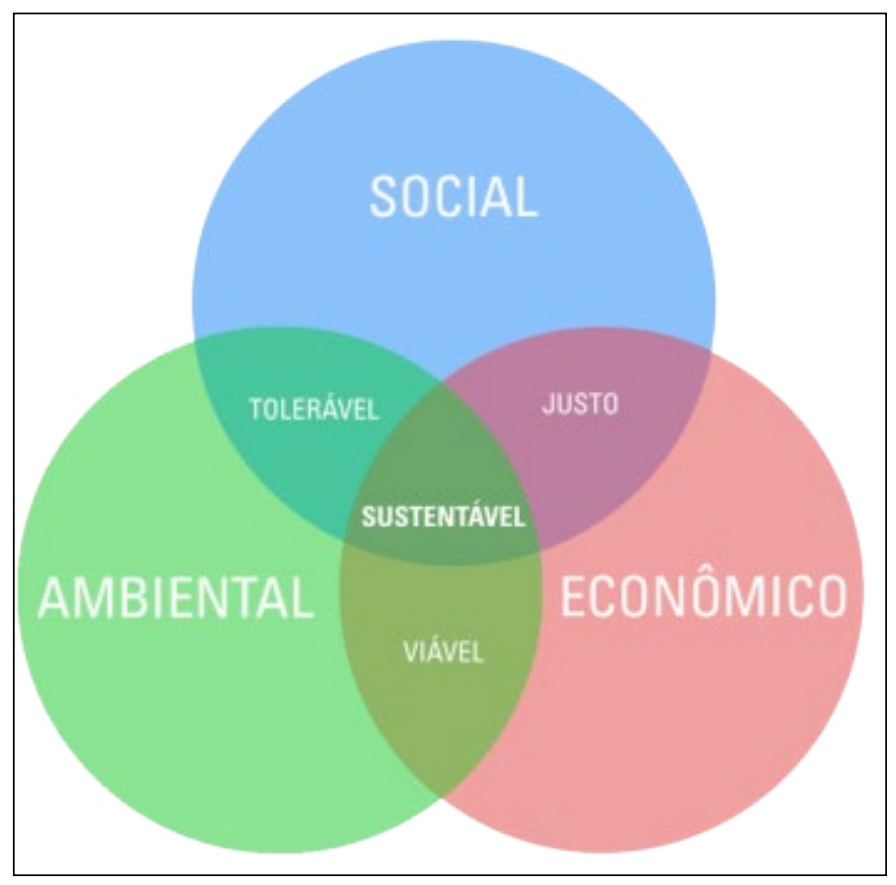

Fonte: Tocha (2015).

Considerada como uma das mais importantes atividades para o desenvolvimento econômico e social, a indústria da construção civil consume grande volume de recursos nãorenováveis retirados da natureza e é responsável pela geração de quantidades exorbitantes de resíduos, poluindo o meio ambiente. Por isso, este segmento vem buscando eficiência e responsabilidade no uso de recursos naturais, utilizando alta tecnologia para reduzir os impactos ambientais (PINTO, 2005 apud KARPINSK et al., 2009).

Em busca dessa harmonização com a natureza, se faz necessário preservá-la de todas as formas possíveis. Na perspectiva de Farias, Medeiros e Freitas (2015, p. 368):

Reduzir a poluição através do uso racional de matéria-prima, água e energia, significa uma opção ambientalmente e economicamente eficiente, tendo em vista que a transformaçáo de recursos naturais em produtos e não em resíduos torna a empresa mais competitiva, além de exigir menores investimentos para soluçóes de problemas ambientais.

Logo, empresas do ramo de construção civil estão buscando alternativas ecológicas para suas edificaçôes. A conscientização e a busca por uma sociedade mais sustentável fomentaram a criação de novas certificações que qualificam edificações de acordo com níveis de sustentabilidade, que são denominadas "construções verdes" ou "construções sustentáveis"; o que estimula uma nova realidade no setor da construção civil, caracterizada por minimizar os impactos gerados ao meio ambiente (GARÉ; PEREIRA, 2012). 
Uma edificação sustentável precisa atender vários requisitos, como o gerenciamento consciente dos resíduos gerados pela construção e pelos usuários ao longo da vida útil da mesma, buscando eficiência dos recursos utilizados, minimizando os impactos causados pela extração da matéria-prima, reduzindo o consumo de solo, água e energia durante a construção e a utilizaçáo da edificação. Essa forma de construir abrange todo seu entorno e modifica conceitos até mesmo culturais dos indivíduos que a frequentam. Logo, este tipo de edificação será responsável por tudo que consome, gera, processa e descarta, por isso é imprescindível prever todos os impactos gerados durante toda sua vida útil. Além disso, uma edificação sustentável utiliza ecomateriais e soluçóes tecnológicas para reduzir a poluiçáo e objetiva melhorar a qualidade do ambiente interno com a mínima utilizaçáo de recursos naturais (KEELER; BURKE, 2010; ARAÚJO, 2008).

Para a concepção de uma edificação sustentável é essencial analisar o uso da matéria-prima desde o início, visando um aproveitamento racional dos recursos naturais, em benefício da preservação da natureza. Por isso, eliminar o conceito de desperdício é fundamental, assim como entender o equilíbrio natural e evitar ao máximo interferir nele. A destruição ambiental é uma ameaça para a vida, por isso o movimento ambientalista vem ganhando força em vários setores econômicos, inclusive na indústria da construção (KEELER; BURKE, 2010).

Por outro lado, adequar um projeto já existente ao conceito de sustentabilidade provoca uma valorizaçáo imobiliária, indicando aumento da qualidade de vida e crescimento econômico, o que atrai investimentos externos (ALMEIDA, 2013).

Além disso, a conscientização da população a respeito das preocupaçóes ambientais impulsiona as empresas a adotarem processos produtivos com menor impacto ambiental. As instituiçôes sociais e o governo também têm papel importante nessa mudança de conceito, pois promovem incentivos à inovação tecnológica e ao aperfeiçoamento da gestão ambiental (FARIAS; MEDEIROS; FREITAS, 2015).

Dessa forma, a construção civil é capaz de reabsorver a maioria dos resíduos que produz, através de reutilização e reciclagem. Em razão disso, é necessário entender como os resíduos são classificados e quais podem passar por esses processos, para assegurar uma gestáo de resíduos ecologicamente consciente.

\section{2- Definiçáo e classificaçáo dos RCC}

O complexo da indústria da construção gera resíduos em todo seu processo, desde a fabricação de seus materiais, passando pelas atividades do canteiro de obras, até a demoliçấo total da edificação. A geração de resíduos da construção civil corresponde, aproximadamente, a 60\% dos resíduos sólidos urbanos (MEDEIROS, 2002 apud KARPINSKI et al., 2009).

A Resolução CONAMA n 307/2002, citada anteriormente classifica os Resíduos da Construção Civil (RCC) de acordo com as classes a seguir:

a) Classe A - são os resíduos reutilizáveis ou recicláveis como agregados, tais como:

- de construção, demolição, reformas e reparos de pavimentação e de outras obras de infraestrutura, inclusive solos provenientes de terraplanagem; 
- de construção, demolição, reformas e reparos de edificaçóes: componentes cerâmicos (tijolos, blocos, telhas, placas de revestimento etc.), argamassa e concreto;

- de processo de fabricaçáo e/ou demolição de peças pré-moldadas em concreto (blocos, tubos, meios-fios etc.) produzidas nos canteiros de obras;

b) Classe B - são os resíduos recicláveis para outras destinaçóes, tais como plásticos, papel, papeláo, metais, vidros, madeiras, embalagens vazias de tintas imobiliárias e gesso; (Redação dada pela Resolução no 469/2015).

c) Classe C - são os resíduos para os quais não foram desenvolvidas tecnologias ou aplicaçóes economicamente viáveis que permitam a sua reciclagem ou recuperação; (Redação dada pela Resolução n 431/2011).

d) Classe D - são resíduos perigosos oriundos do processo de construção, tais como tintas, solventes, óleos e outros ou aqueles contaminados ou prejudiciais à saúde oriundos de demolições, reformas e reparos de clínicas radiológicas, instalaçôes industriais e outros, bem como telhas e demais objetos e materiais que contenham amianto ou outros produtos nocivos à saúde; (Redaçáo dada pela Resoluçáo nº 348/2004).

O impacto gerado pela indústria da construção civil ao meio ambiente é preocupante. Este setor destaca-se por ser o maior produtor de resíduos (GARÉ; PEREIRA, 2012). O que justifica a importância de uma reflexão sobre as suas consequências na natureza e, consequentemente, da busca por novas soluçóes que sejam menos degradantes ao meio ambiente para o descarte desses resíduos.

\section{3- Reduçáo, reutilizaçáo e reciclagem de RCC}

A gestão sustentável de resíduos prioriza a redução da geração de resíduos na fonte. Caso a geração de resíduo seja inevitável, procura-se reutilizá-los ou reciclá-los. Quando não for possível fazer a reutilização ou a reciclagem, os resíduos devem ser incinerados (com recuperação de energia) ou aterrados. Os resíduos orgânicos podem ser utilizados como adubo para o solo depois de passarem pelo processo de compostagem (CORREAA, 2009; KARPINSKI et al., 2009).

A reciclagem na construção civil resulta em incontáveis benefícios, como a redução da extração de recursos não-renováveis da natureza, a diminuição de áreas para aterros devido à redução do volume de resíduos e a redução do consumo de energia, tudo isso causa redução da poluição (PINTO, 1999 apud ÂNGULO; ZORDAN; JOHN, 2001).

Para que o processo de reciclagem atinja o desempenho máximo é imprescindível o uso de resíduos de boa qualidade, o que implica em fazer a correta segregaçáo dos resíduos junto a fonte geradora, ou seja, nos próprios canteiros de obra. Logo, o construtor/gerador precisa ter consciência do importante papel que desempenha nesse processo. Para ser possível a reciclagem dos resíduos, então, é necessário um Plano de Gerenciamento de Resíduos em cada obra, efetuando a separação correta dos resíduos rotineiramente, o que implica na conscientização e na instrução da mão de obra (CORRÊA, 2009).

\section{4- Gestão de resíduos da construçáo civil}

A Resolução CONAMA no 307/2002 citada anteriormente, define essa gestão como um processo que visa reduzir, reutilizar ou reciclar os resíduos. Para que isso ocorra é realizado um planejamento e definido responsabilidades, práticas, procedimentos e recursos 
de cada agente envolvido na gestão dos resíduos, para que todas as ações determinadas pelos programas e planos sejam executadas. Isto é, o gerenciamento dos resíduos realizado pelos geradores é uma etapa determinante para que a gestáo de resíduos ocorra da maneira correta.

Este processo de gestão é responsabilidade de vários setores. Dentre eles estáo os geradores, que são pessoas físicas ou jurídicas que executam alguma atividade geradora de resíduos; os transportadores, encarregados pela coleta desses resíduos e o direcionamento destes para as áreas de destinação; os destinatários, que são áreas designadas ao beneficiamento ou disposição final desses resíduos; os agentes licenciadores ou de fiscalização, que são órgãos públicos que verificam o cumprimento dos requisitos legais das atividades geradoras, dos transportadores, e das áreas de destinação final; fornecedores, que fornecem produtos ou serviços para os geradores e têm importante papel no processo de logística reversa; clientes, que adquirem bens ou serviços dos geradores de resíduos; consultores, que orientam geradores, transportadores e destinatários no cumprimento da legislação; auditores, que verificam o cumprimento dos requisitos técnicos e legais; e pesquisadores, que aprimoram os processos e materiais para dar uma destinaçâo mais ecologicamente consciente aos mesmos (NAGALLI, 2014).

A Figura 2 ilustra os principais agentes responsáveis pela gestão dos resíduos e a relação entre eles.

Figura 2 - Relacionamento entre os agentes do sistema de gestão de RCC

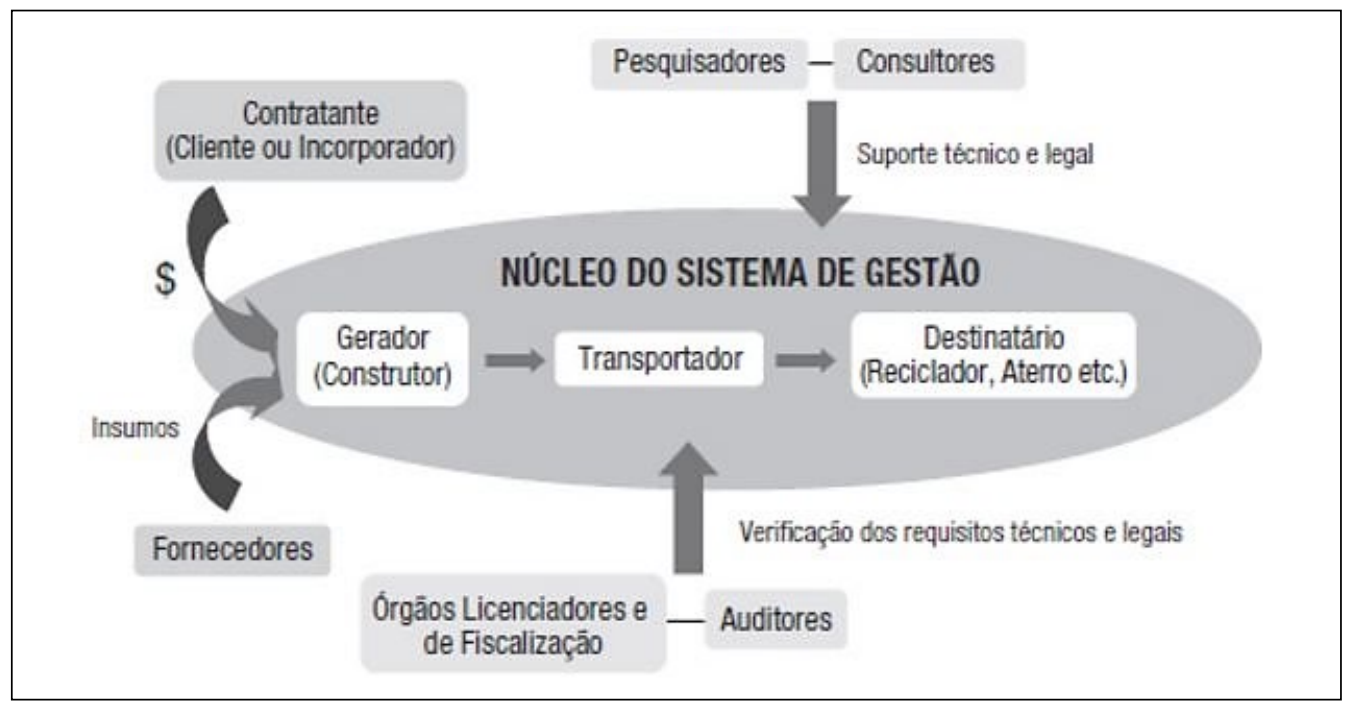

Fonte: Nagalli (2014).

A gestão integrada de resíduos utiliza várias técnicas, como a redução de resíduos, compostagem, incineração, aterros sanitários e reciclagem. Um incentivo à gestão correta dos resíduos da construção é encará-los como fonte de matéria-prima que podem ser reciclados e reutilizados em outras edificações (KEELER; BURKE, 2010). A Figura 3 exemplifica o sistema da gestáo integrada. 
Figura 3 - Hierarquia do sistema de gestão integrada dos resíduos

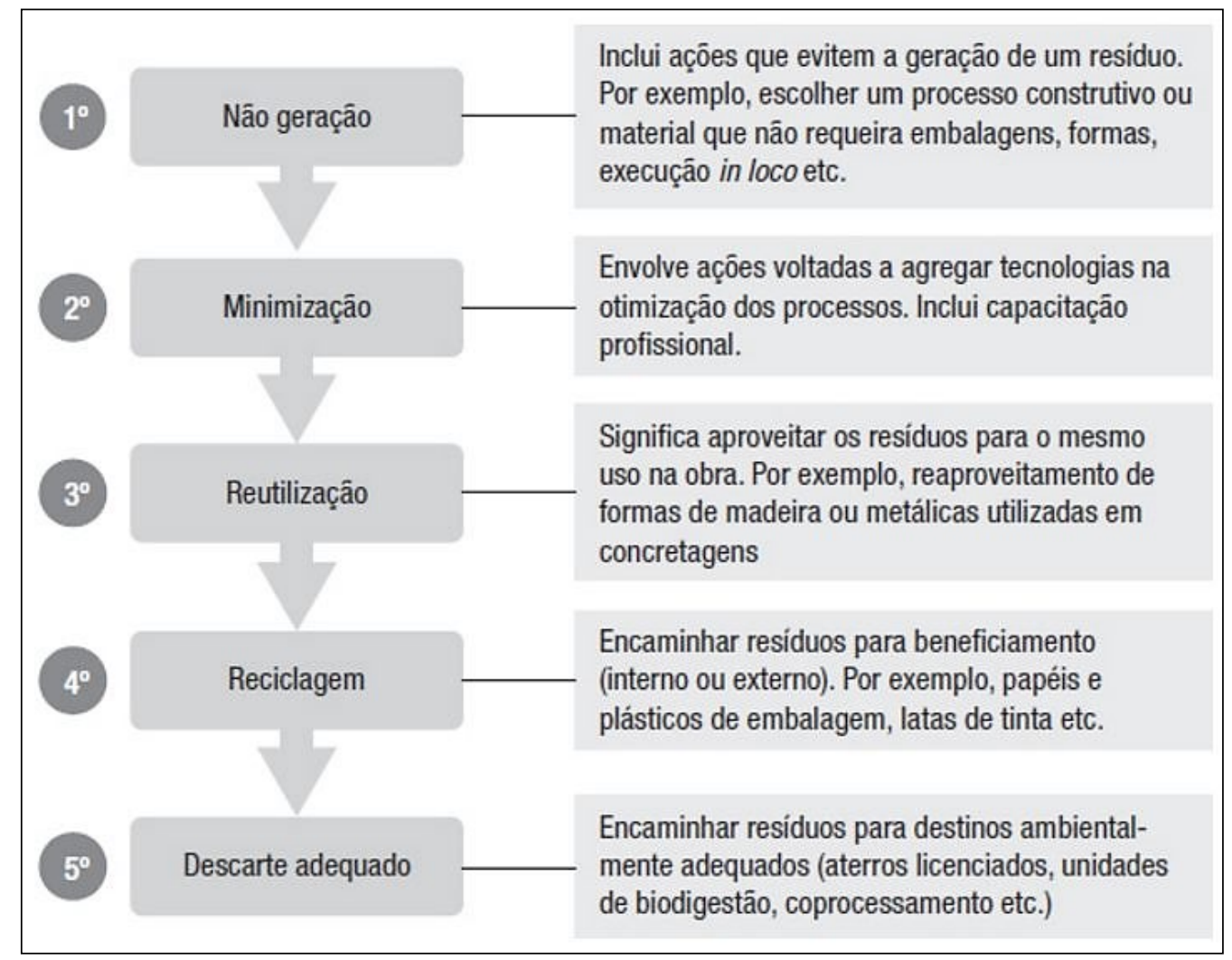

Fonte: Nagalli (2014).

Ademais, a Resolução CONAMA no 307/2002 regulamenta a criação do Plano Municipal de Gestão de Resíduos da Construção Civil (PMGRCC) a ser elaborado pelo poder legislativo dos municípios e do Distrito Federal. Esse plano define as obrigaçóes das Prefeituras Municipais, dos geradores e dos transportadores perante a gestão dos RCC. Além disso, ele instrui a destinação correta dos RCC e dos grandes volumes. A Figura 4 define o fluxo do gerenciamento. 
Figura 4 - Fluxograma do gerenciamento de RCC

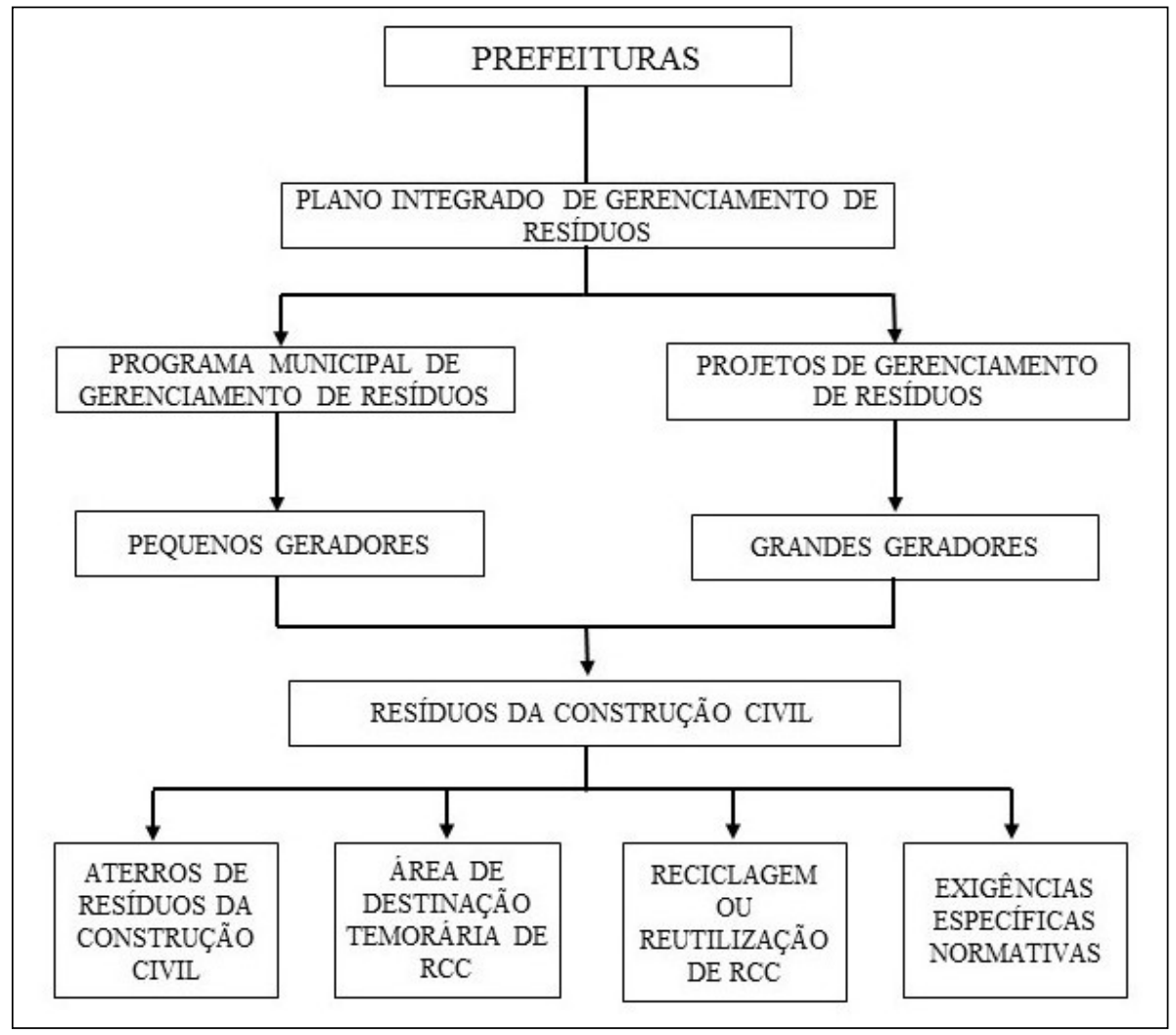

Fonte: Adaptado de CARNEIRO (2005) apud KARPINSKI et al. (2009).

A gestão dos resíduos de construçáo civil no Brasil, contudo, ainda possui muitos problemas e dificuldades, mas essa realidade vem se alterando com o avanço da tecnologia implantada nesse sistema de gestão, incentivado pela criação de novas normas e leis que orientam sobre a melhor maneira de realizar esse descarte, promovendo o reaproveitamento e a reciclagem do que ainda pode ser utilizado.

\section{3- Metodologia}

A seguir apresentar-se-á a metodologia utilizada na realização desta pesquisa, demonstrando os procedimentos que deram o embasamento necessário a todas as etapas do estudo. Para isso, realizou-se levantamentos de dados, que permitiram identificar a atual gestão dos resíduos na cidade de Primavera do Leste-MT.

\section{1- Caracterizaçáo da pesquisa}

O presente estudo contém revisão bibliográfica, que define e classifica os RCC, abordando os impactos gerados devido à deposiçáa inadequada desses resíduos; 
fundamentando-se no posicionamento de vários autores, em busca de um maior suporte teórico.

Quanto à sua abordagem, esta pesquisa classifica-se como quantitativa e qualitativa, pois o desenvolvimento deste estudo baseia-se em dados numéricos, em opinióes das pessoas vinculadas à gestão dos RCC e na observação do autor. Logo, a pesquisa pode ser classificada como exploratória e descritiva (SILVA; MENEZES, 2005).

Como consequência, tornou-se possível verificar se o atual direcionamento dos RCC na cidade está de acordo com as leis e as normas brasileiras. Por isso, foram realizadas diversas etapas da pesquisa para coletar dados numéricos e informaçóes pertinentes. $\mathrm{O}$ Quadro 1 ilustra as etapas da pesquisa e define os objetivos de cada uma.

Quadro 1 - Delimitação da pesquisa

\begin{tabular}{|l|l|}
\hline \multicolumn{1}{|c|}{ ETAPAS } & \multicolumn{1}{c|}{ OBJETIVOS } \\
\hline Etapa 1- Prefeitura Municipal & Examinar a gestão de resíduos realizada pela Prefeitura Municipal. \\
\hline Etapa 2- Coletores privados & $\begin{array}{l}\text { Estimar a quantidade de RCC gerados com base nos dados dos serviços } \\
\text { dos coletores privados. }\end{array}$ \\
\hline Etapa 3- Construtoras & $\begin{array}{l}\text { Verificar o gerenciamento de resíduos de quatro empresas aplicadas nas } \\
\text { suas respectivas obras. }\end{array}$ \\
\hline Etapa 4- Melhorias na Gestão & $\begin{array}{l}\text { Identificar as principais falhas na gestão atual e propor melhorias para } \\
\text { adequá-la a gestão integrada de resíduos. }\end{array}$ \\
\hline
\end{tabular}

Fonte: Do Autor (2017).

Ao analisar a gestão atual dos resíduos no município, deve-se considerar que é necessário observar o posicionamento da Prefeitura Municipal, das empresas coletoras e dos geradores de resíduos em relação à deposição de RCC.

\section{Etapa 1 - Prefeitura Municipal}

A Etapa 1 teve como objetivo caracterizar a atual gestão de resíduos da construção civil adotada pela Prefeitura Municipal. Para obter os resultados necessários realizou-se uma entrevista, em janeiro de 2017, com o engenheiro sanitarista Valdir de Jesus Santos, da Secretaria de Desenvolvimento da Industria, Comércio, Agricultura e Meio Ambiente. O Quadro 2 apresenta o roteiro da entrevista realizada.

Quadro 2 - Questionário sobre a gestão de resíduos da construção civil no município

1) Segundo o Art. $05^{\circ}$ da Resolução CONAMA no 307/2002: "é instrumento para a implementação da gestáo dos RCC o Plano Municipal de Gestão de Resíduos da Construção Civil (PMGRCC) ”. A Prefeitura possui este plano?

2) Conforme o parágrafo 1 do Art. $04^{\circ}$ da Resolução citada anteriormente: "os RCC não poderão ser dispostos em aterros de resíduos sólidos urbanos". Existe aterro específico para os RCC gerados? Se negativo, onde são depositados? 
3) De acordo com o Art. $08^{\circ}$ da Resoluçáo "os grandes geradores deverão elaborar e implementar o Plano de Gerenciamento de Resíduos da Construção Civil (PGRCC), tendo como objetivo estabelecer os procedimentos necessários para o manejo e destinação ambientalmente adequados". É exigido e cobrado a devida realização e implantação deste Plano?

4) De quem é a responsabilidade de fiscalizar as empresas de construçấo civil quanto ao gerenciamento utilizado para os resíduos gerados?

5) A Prefeitura disponibiliza pontos para a entrega voluntária de pequenas quantidades de RCC e resíduos volumosos? Onde estáo localizados esses EcoPontos?

6) Existe alguma Lei Municipal referente a gestão dos RCC?

7) Há algum controle da quantidade de RCC gerados?

8) Segundo o Capítulo IV da Lei n 7.862: "o município deve incentivar à não geração, minimização, reutilização e reciclagem dos RCC”. A Prefeitura já realizou/realiza projetos, cursos, palestras para a conscientização da população?

9) A cidade possui Usina de Reciclagem de RCC?

10) Qual é a quantidade de resíduos sólidos domiciliares transportada diariamente ao aterro municipal?

11) Quantas empresas coletoras de resíduos existem na cidade?

Fonte: Do Autor (2017).

\section{Etapa 2 - Coletores privados}

A Etapa 2 consistiu em obter os dados referentes à coleta dos RCC realizadas pelas empresas privadas. Essa etapa tem como objetivo estimar a geração de resíduos da construção civil através do volume transportado pelos coletores num período de 12 meses, de janeiro de 2016 a janeiro de 2017. Para isso, foi realizada uma pesquisa com todas as cinco coletoras instaladas na cidade. O Quadro 3 apresenta o questionário aplicado aos coletores de RCC.

\section{Quadro 3 - Questionário aplicado aos coletores privados}

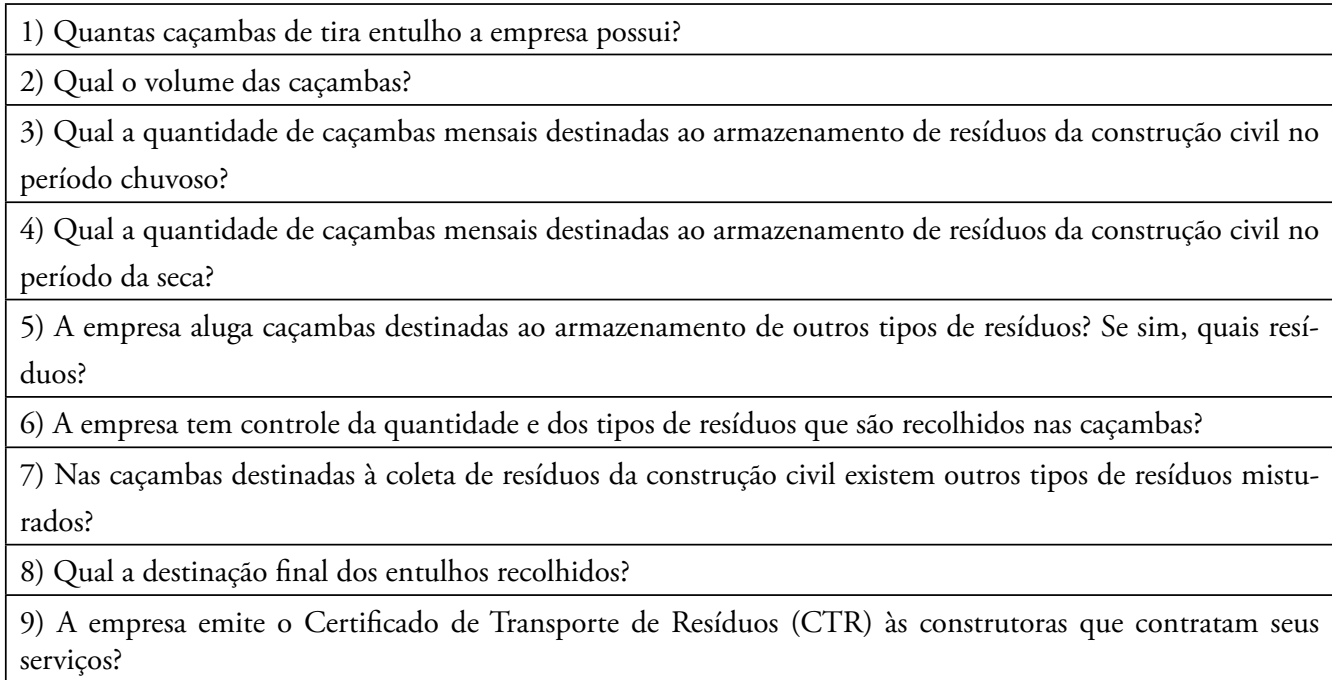

Fonte: Do autor (2017). 


\section{Etapa 3 - Construtoras}

A Etapa 3 compreendeu a verificação dos gerenciamentos de resíduos adotada por construtoras atuantes na cidade. Para isso, foram analisadas cinco obras de quatro empresas diferentes. Foi aplicado um questionário a respeito da obra em questáo, e uma lista de verificação, composta por 32 itens que abrangem 6 temas (organização e limpeza no canteiro de obras; transporte e armazenamento de materiais; reutilização e reciclagem de resíduos; destinação dos resíduos; legislação e fiscalização e práticas ecologicamente conscientes). São questôes fechadas, com opçóes de resposta: sim, quando o aspecto verificado no canteiro atende a Resolução CONAMA n ${ }^{\circ}$ 307/2002; não, quando há alguma desconformidade e não se aplica. A lista de verificação foi preenchida a partir de visitas aos canteiros de obras analisados. Alguns dados foram obtidos a partir de informaçóes fornecidas pelas construtoras. A seguir estão presentes o questionário aplicado e a lista de verificação, nos Quadros 4 e 5, respectivamente.

Quadro 4 - Questionário aplicado às Construtoras

\begin{tabular}{|l|}
\hline Obra (endereço): \\
\hline Tipo de obra: \\
\hline Etapa da obra: \\
\hline Número de pavimentos ou unidades: \\
\hline Número de funcionários trabalhando na obra: \\
\hline Mão de obra própria ou terceirizada? \\
\hline Data de previsão do término da obra: \\
\hline $\begin{array}{l}\text { Além dessa obra, por quantos outros empreendimentos localizados no município a construtora é responsável } \\
\text { atualmente? }\end{array}$ \\
\hline
\end{tabular}

Fonte: Do autor (2017).

Quadro 5 - Lista de verificação aplicada às Construtoras

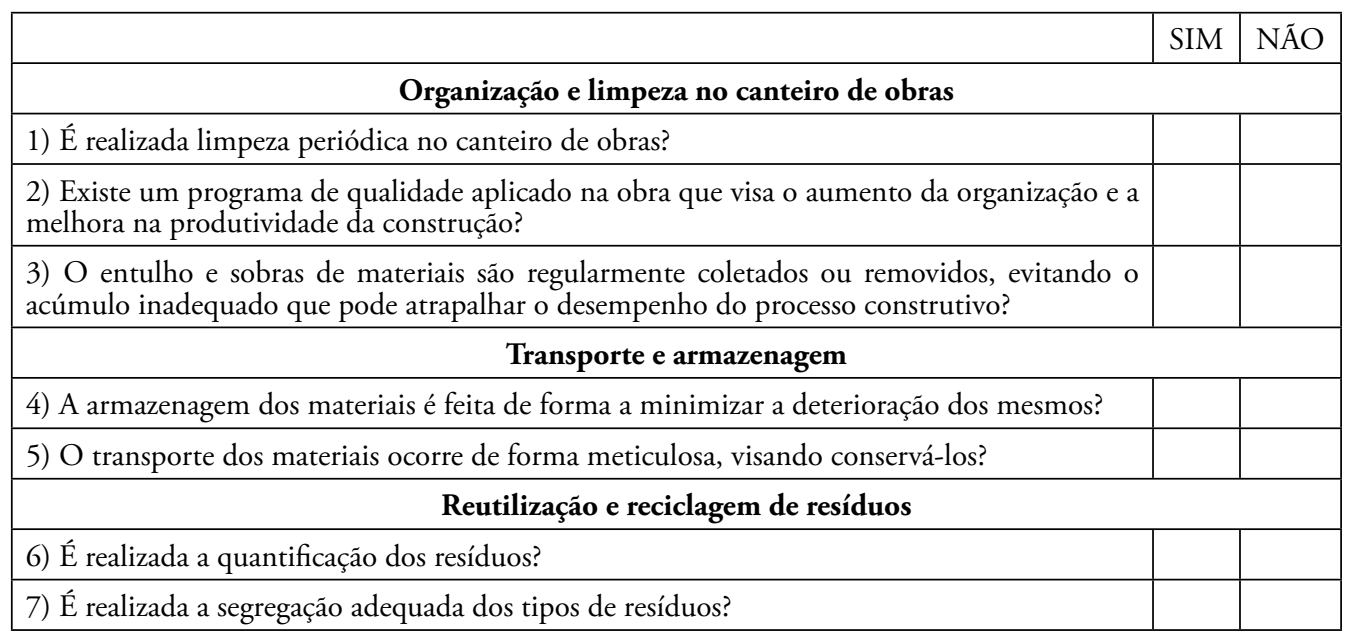




\begin{tabular}{|c|c|c|}
\hline & SIM & NÂO \\
\hline $\begin{array}{l}\text { 8) A obra possui uma Central de Resíduos (conjunto de estruturas destinado à gerência, } \\
\text { triagem e armazenamento temporários de resíduos)? }\end{array}$ & & \\
\hline $\begin{array}{l}\text { 9) A construtora orienta os funcionários à coleta segregada dos resíduos de acordo com a } \\
\text { classificação de cada um? }\end{array}$ & & \\
\hline $\begin{array}{l}\text { 10) Existem áreas para armazenar separadamente todo o resíduo gerado, de acordo com sua } \\
\text { classe? }\end{array}$ & & \\
\hline $\begin{array}{l}\text { 11) Visto que alguns resíduos que fazem parte da mesma classe não podem passar pelo } \\
\text { mesmo processo de reciclagem, os resíduos gerados são armazenados em baias diferentes } \\
\text { para facilitaçáo do processo de reciclagem? }\end{array}$ & & \\
\hline $\begin{array}{l}\text { 12) As áreas para armazenamento são sinalizadas para orientar o tipo de resíduo que deve ser } \\
\text { armazenado naquele local? }\end{array}$ & & \\
\hline 13) Existe um ambiente propício ao armazenamento de resíduos perigosos? & & \\
\hline 14) A construtora emprega algum tipo de reciclagem interna no canteiro de obras? & & \\
\hline 15) A construtora realiza a reutilização de algum resíduo? & & \\
\hline \multicolumn{3}{|l|}{ Destinaçáo dos resíduos } \\
\hline $\begin{array}{l}\text { 16) Os resíduos de classe A são encaminhados para reciclagem ou aterros de reservação de } \\
\text { material para usos futuros? }\end{array}$ & & \\
\hline $\begin{array}{c}\text { 17) Os resíduos de classe B são encaminhados para reciclagem ou áreas de armazenamento } \\
\text { temporário? }\end{array}$ & & \\
\hline $\begin{array}{l}\text { 18) Os resíduos de classe C são encaminhados para áreas de transbordo e triagem ou aterros } \\
\text { sanitários preparados para seu recebimento? }\end{array}$ & & \\
\hline $\begin{array}{l}\text { 19) Os resíduos de classe D são encaminhados para aterros industriais licenciados para } \\
\text { receber produtos deste tipo? }\end{array}$ & & \\
\hline $\begin{array}{l}\text { 20) As embalagens de tintas são submetidas à logística reversa, onde os fabricantes darão } \\
\text { destinaçáo ambientalmente adequada aos restos de tintas e às embalagens? }\end{array}$ & & \\
\hline 21) A construtora contrata caçambas de tira entulho? & & \\
\hline \multicolumn{3}{|l|}{ Legislação e fiscalizaçáo } \\
\hline \multicolumn{3}{|l|}{$\begin{array}{l}\text { 22) A obra possui o Plano de Gerenciamento de Resíduos da Construção Civil, conforme } \\
\text { exigido pela Resoluçáo CONAMA } 307 / 2002 \text { ? }\end{array}$} \\
\hline \multicolumn{3}{|l|}{ 23) A empresa de caçambas contratada emite o Certificado de Transporte de Resíduos (CTR)? } \\
\hline \multicolumn{3}{|l|}{$\begin{array}{l}\text { 24) O transporte dos resíduos perigosos é feito por empresas especializadas nesse tipo de } \\
\text { material? }\end{array}$} \\
\hline \multicolumn{3}{|l|}{$\begin{array}{l}\text { 25) A construtora tem conhecimento sobre a Lei Municipal nº 1420/2014 que institui o } \\
\text { Código Municipal de Gestáo de Resíduos Sólidos? }\end{array}$} \\
\hline \multicolumn{3}{|l|}{ 26) A Lei Municipal n 1420/2014 é executada na obra? } \\
\hline \multicolumn{3}{|l|}{ 27) Os órgãos públicos fiscalizam a obra com frequência? } \\
\hline \multicolumn{3}{|l|}{ 28) A Prefeitura orienta sobre a destinaçáo correta dos RCC? } \\
\hline \multicolumn{3}{|l|}{ Práticas ecologicamente conscientes } \\
\hline \multicolumn{3}{|l|}{$\begin{array}{l}\text { 29) A construtora prioriza contratos com fornecedores que realizam a coleta das embalagens } \\
\text { utilizadas? }\end{array}$} \\
\hline \multicolumn{3}{|l|}{ 30) A obra utiliza algum tipo de produto reciclado advindo de fornecedores externos? } \\
\hline \multicolumn{3}{|l|}{ 31) A obra possui coleta seletiva de lixo doméstico? } \\
\hline $\begin{array}{l}\text { 32) Os funcionários são orientados para minimizar as perdas de materiais durante todo o } \\
\text { processo construtivo? }\end{array}$ & & \\
\hline
\end{tabular}

Fonte: Do autor (2017). 


\section{Etapa 4 - Melhorias na Gestáo}

Essa etapa foi baseada na observação da atual gestão e no referencial teórico anteriormente apresentado, analisando as principais diferenças entre a gestão aplicada no município e a gestão adequada a observância de leis, normas e resoluçóes brasileiras.

\section{4- Resultados e discussóes}

\section{1- Gestão de RCC adotada no município de Primavera do Leste-MT}

A Resolução CONAMA 307/2002 estabeleceu que todos os municípios brasileiros e o Distrito Federal deveriam elaborar seus respectivos Planos Municipais de Gestão de Resíduos da Construção Civil (PMGRCC) até janeiro de 2004. A Resolução CONAMA $448 / 2012$, entretanto, alterou esse prazo para janeiro de 2013 e sua implantação para julho desse mesmo ano.

Apesar de possuir o PMGRCC e Lei Municipal concernente à gestão de resíduos da construção civil, o município não possui nenhum órgão responsável por fiscalizar e aplicar as exigências deles.

O município de Primavera do Leste, em 01 de abril de 2014, aprovou a Lei $\mathrm{n}^{\circ} 1420$, que institui o Código Municipal de Gestão de Resíduos Sólidos e disciplina sobre a limpeza urbana no município. A gestão dos resíduos da construção civil e resíduos volumosos obedece às normatizaçóes específicas do Plano Municipal Integrado de Gerenciamento de Resíduos Sólidos, que define uma rede de pontos de entrega para pequenos volumes, uma rede de áreas para recepção de grandes volumes, açóes para a informação e educação ambiental da população, ações para controle e fiscalização de obras e posturas, açóes de gestão integrada a ser desenvolvida pelo Núcleo Permanente de Gestão, açóes de incentivo a reutilização e redução dos resíduos na fonte de produção e ações de incentivo à instalação de empresas recicladoras no município, dentre outras regulamentaçóes.

Apesar disso, o município não possui aterro específico para armazenamento de RCC, sendo que esses são depositados no lixão, juntamente com outros resíduos sólidos, não respeitando a regulamentação.

De acordo com a Resolução CONAMA 307/2002, os grandes geradores de resíduos da construção civil devem elaborar um Plano de Gerenciamento de Resíduos da Construção Civil (PGRCC) para cada obra e dar destinação ambientalmente adequada para todos os tipos de resíduos. O PMGRCC do município também regulamenta outras obrigaçóes dos grandes e dos pequenos geradores.

Porém, de acordo com a Coordenadoria de Meio Ambiente da Secretaria de Desenvolvimento da Indústria, Comércio, Agricultura e Meio Ambiente, devido à falta de um órgão fiscalizador, as normatizaçóes não são executadas, por isso nenhuma empresa que atua no ramo da construção civil possui o PGRCC. Ou seja, os geradores de RCC não são responsabilizados pela sua destinação; logo, o descarte desses resíduos não está de acordo com a Resolução supracitada. 
Além disso, a Prefeitura Municipal não tem nenhum controle sobre a quantidade de resíduos provenientes da construção civil que são depositados diariamente no lixão. Conforme observado no local, os RCC são depositados juntamente com outros resíduos sólidos, não havendo nenhuma separação entre eles.

O município dispóe de, aproximadamente, 24 EcoPontos ativos, que são locais destinados ao depósito de RCC e resíduos volumosos, abertos à população. Contudo, não há avisos e placas orientando os moradores a não descartarem outros tipos de resíduos nesses locais, por isso ocorre descarte de resíduos inadequados, o que gera impactos ambientais. Além disso, os resíduos coletados nesses pontos de entrega voluntária são encaminhados para o lixão municipal, o que contribui para a degradação da natureza. Os EcoPontos só impedem que a população descarte os resíduos em locais inapropriados, o que causaria mais transtornos sociais e contaminação ambiental.

Além da deposição irregular realizada nos EcoPontos, existem alguns lotes vagos onde os moradores depositam entulhos ilegalmente, ou seja, sem o consentimento dos proprietários dos lotes.

\section{2- Estimativa da geração de resíduos da construção civil}

A estimativa da geração de RCC no município de Primavera do Leste-MT foi realizada com base nas informaçóes provenientes dos coletores de entulho privados. Existem cinco empresas particulares que realizam a coleta e o descarte de entulho atuando na cidade.

Essas empresas locam caçambas para as construtoras e são encarregadas de levar os resíduos recolhidos até o lixão. Três coletores afirmaram emitir o Certificado de Transporte de Resíduos (CTR) quando solicitado pelo locatário, porém, raramente isso acontece. Além disso, os cinco coletores relatam que outros resíduos são misturados aos RCC nas caçambas.

Algumas empresas locam caçambas destinadas ao armazenamento de outros resíduos, como restos de alimentos provenientes de refeitórios e, também, óleos e graxas advindos de oficinas mecânicas.

O Quadro 6 apresenta as informaçóes relacionadas à quantidade de caçambas e ao volume delas de cada empresa coletora de resíduos.

Quadro 6 - Quantidade e volume das caçambas

\begin{tabular}{|l|c|c|}
\hline \multicolumn{1}{|c|}{ Empresa } & Quantidade de caçambas & Volume das caçambas $\left(\mathrm{m}^{3}\right)$ \\
\hline Empresa A & 87 & 4,5 e 5 \\
\hline Empresa B & 98 & 4 e 5 \\
\hline Empresa C & 20 & 5 e 6 \\
\hline Empresa D & 55 & 4 e 5 \\
\hline Empresa E & 219 & 3,5 e 5 \\
\hline
\end{tabular}

Fonte: Do autor (2017).

Para calcular o volume de RCC gerado será considerado o número de caçambas locadas para o armazenamento desses resíduos e será adotado um volume médio de 4,6 
$\mathrm{m}^{3}$, já que existem caçambas de 3,5; 4; 4,5; 5 e $6 \mathrm{~m}^{3}$ e não há controle da locação em relaçáo a capacidade delas. O período de chuva compreende os meses de novembro a março, totalizando cinco meses, e o período de seca vai de abril a outubro, num total de sete meses. O Quadro 7 apresenta a quantidade média de RCC coletados por cada empresa, nos períodos de chuva e seca referentes ao ano de 2016.

Quadro 7 - Quantidade média de RCC coletados

\begin{tabular}{|c|c|c|}
\hline \multirow{2}{*}{ Empresa } & \multicolumn{2}{|c|}{ Quantidade de caçambas por mês contendo RCC } \\
\hline & Período de chuva & Período de seca \\
\hline Empresa A & 110 & 150 \\
\hline Empresa B & 127 & 146 \\
\hline Empresa C & 35 & 52 \\
\hline Empresa D & 40 & 45 \\
\hline Empresa E & 200 & 250 \\
\hline TOTAL & 512 & 643 \\
\hline
\end{tabular}

Fonte: Do autor (2017).

De acordo com os dados do Quadro 3 percebe-se que foram recolhidas 1155 caçambas de RCC em um período de 12 meses.

Para obter o valor quantitativo de RCC no município de Primavera do Leste-MT, relacionado com o número de habitantes para o ano de 2016, que é estimado em 58370 conforme o IBGE, será considerado a média da massa específica do entulho, que é de 1156 $\mathrm{kg} / \mathrm{m}^{3}$ (CARNEIRO et al., 2001). O Quadro 8 apresenta a estimativa do volume de RCC gerado no município.

Quadro 8 - Estimativa do volume de RCC gerado no município

\begin{tabular}{|c|l|}
\hline \multicolumn{2}{|c|}{ Estimativa do volume de RCC } \\
\hline \multirow{3}{*}{ Período de chuva } & Coleta mensal: $2722,6112 \mathrm{t} / \mathrm{mês}$ \\
\cline { 2 - 3 } & Coleta diária: $104,7158154 \mathrm{t} / \mathrm{dia}$ \\
\cline { 2 - 2 } & Coleta diária por habitante: $1,794 \mathrm{~kg} /$ dia $/$ habitante \\
\hline \multirow{3}{*}{ Período de seca } & Coleta mensal: $3419,2168 \mathrm{t} / \mathrm{mês}$ \\
\cline { 2 - 2 } & Coleta diária: $131,5083385 \mathrm{t} / \mathrm{dia}$ \\
\cline { 2 - 2 } & Coleta diária por habitante: $2,253 \mathrm{~kg} /$ dia $/$ habitante \\
\hline Coleta diária por habitante & 0,0021 t/habitante $/$ dia \\
\hline Coleta anual por habitante & 0,75 t/habitante/ano \\
\hline
\end{tabular}

Fonte: Do autor (2017).

No Brasil, a média de geração de RCC per capita por ano é de 0,5 t/habitante/ano (FERREIRA; NOSCHANG; FERREIRA, 2009). Logo, no município de Primavera do Leste a estimativa é 50\% maior que a média nacional, totalizando 0,75 t/habitante/ano. 
Outrossim, o município de Rondonópolis possui população estimada em 211.718 habitantes, e estimativa de volume de RCC 0,16 t/habitante/ano (TOMAZELE, 2015). Já o município de Barra do Garças tem estimativa de geração de RCC de 0,8 t/habitante/ ano, e um número de habitantes estimado em 57.791 (MAGNI, 2014). Tal diferença pode ser explicada pelo porte dos municípios, bem como pela expansão da construção civil em Rondonópolis.

De acordo com a Prefeitura Municipal, são transportados diariamente cerca de 120 toneladas de resíduos domiciliares ao lixão. O Quadro 9 relaciona a quantidade média mensal de RCC com a quantidade média mensal de resíduos domiciliares.

Quadro 9 - Porcentagem dos tipos de resíduos depositados no lixão municipal

\begin{tabular}{|c|c|c|}
\hline \multicolumn{1}{|c|}{ Tipo de resíduos } & Estimativa de resíduos $(\mathrm{t} /$ dia $)$ & Estimativa de resíduos $(\%)$ \\
\hline Resíduos da construçáo civil & 120,34 & 50,07 \\
\hline Resíduos domiciliares & 120 & 49,93 \\
\hline TOTAL & 240,34 & 100 \\
\hline
\end{tabular}

Fonte: Do autor (2017) a partir de dados fornecidos pela Prefeitura Municipal de Primavera do Leste.

A geração de RCC diária supera a geração de resíduos domiciliares, o que preocupa sob o ponto de vista ambiental, social e econômico; retratando a necessidade da mudança da gestão atual e, também, no gerenciamento das obras. Esse resultado faz um alerta ao possível desperdício de materiais que pode estar ocorrendo nos canteiros de obras da cidade.

\section{3- Gerenciamento de RCC aplicado nas obras}

Para obter o diagnóstico do gerenciamento atual de RCC realizados pelas construtoras do município foram verificados os gerenciamentos aplicados nas cinco obras a seguir: Edifício Privilège, Edifício Riviera Campo Grande, Residencial Guterres, Residencial Portal das Águas e Edifício localizado na Avenida Campo Grande que ainda não possui nome.

Conforme já mencionado, a lista de verificação foi dividida em: organização e limpeza no canteiro de obras; transporte e armazenagem de materiais; reutilização e reciclagem de resíduos; destinação correta dos resíduos; legislação e fiscalização e práticas ecologicamente conscientes.

O índice de organização e limpeza nos canteiros é alto, demonstrando, assim, a preocupação das construtoras acerca da manutenção do canteiro de obras, tendo em vista que manter a obra limpa e organizada ajuda na produtividade e minimiza índices de acidentes.

O tópico referente ao transporte e à armazenagem de materiais examina o cuidado que os funcionários possuem na hora de transportar e armazenar os materiais. Isso está intimamente ligado à origem de resíduos antes mesmo do processo construtivo. $\mathrm{O}$ correto manuseio e estocagem desses materiais pode evitar perdas econômicas e diminuir o volume de RCC produzido. 
As políticas adotadas atualmente nessas construtoras não visam a reutilização, nem a reciclagem de resíduos, o que é preocupante, pois essas práticas viabilizam a redução do consumo de matéria-prima.

No que diz respeito à correta destinação dos RCC, a situação é consternadora, pois as medidas tomadas não estão de acordo com a Resolução CONAMA no 307/2002. Nenhuma construtora encaminha os RCC de Classe D, que são considerados resíduos nocivos e perigosos, para aterros industriais licenciados para receber esse tipo de produto. Logo, a deposição desses resíduos é feita de forma inadequada nas obras estudadas.

O índice de cumprimento da legislação e a fiscalização do poder público é baixo, todas as construtoras afirmaram não desempenhar as ações exigidas na Lei Municipal $\mathrm{n}^{\circ}$ 1420/2014. Apenas uma afirmou possuir o Plano de Gerenciamento de RCC exigido pela Resolução CONAMA 307/2002. Além disso, nenhuma construtora exige a emissão do CTR pelas empresas coletoras.

Algumas das obras visitadas abrangem práticas que demonstram preocupação ecológica, o que mostra que os responsáveis pelas construtoras têm conhecimento dos danos que esse setor causa ao meio ambiente. Essas práticas são simples, mas afetam positivamente a preservação do equilíbrio ecológico. Um exemplo foi o resultado positivo em todas as obras no tocante ao treinamento dos funcionários para redução das perdas de materiais durante todo o processo construtivo. Tal procedimento é bastante eficaz e gera grandes benefícios ao gerenciamento de RCC dentro do canteiro de obras.

Observando os tópicos analisados percebe-se que a situação da gestão de RCC no município de Primavera do Leste é preocupante. É necessário, portanto, buscar melhorias para implantar uma gestão ecologicamente consciente.

\section{4- Sugestóes de melhorias a partir do diagnóstico realizado}

O principal responsável pela mudança na gestão dos RCC no município, sem dúvidas, é o poder público, pois através de leis pode garantir que os geradores e coletores adotem a gestão adequada. No entanto, Primavera do Leste já possui uma legislação vigente sobre os resíduos sólidos, a Lei $\mathrm{n}^{\circ} 1420$ de 2014. O grande problema é que o município não possui nenhum órgão responsável por fiscalizar os geradores e os coletores. Por isso, a gestão adotada não condiz com aquilo que a Resolução CONAMA no 307/2002 exige. Além disso, o município já possui o PMGRCC, porém ele não é aplicado.

Outrossim, existe uma dificuldade na obtenção de informaçôes junto a Prefeitura Municipal, pois não há um banco de dados que dispóe de todas as informaçóes acerca do gerenciamento dos RCC aplicados pelas construtoras.

Ademais, não há fiscalização junto aos EcoPontos, nem mesmo placas orientando a população sobre quais tipos de resíduos podem ser descartados naquele local, por isso há descarte de vários tipos de resíduos, inclusive resíduos perigosos e domiciliares.

O maior problema do município acerca da gestão dos resíduos, todavia, ainda é o lixão municipal, que se encontra em péssimas condições e quase com sua capacidade máxima sendo ultrapassada. 
A primeira mudança que deve ocorrer para adequar a gestão de resíduos do município à legislação é a implantação de um aterro sanitário, onde os resíduos sejam separados e devidamente armazenados, para que o lixo orgânico passe pelo processo correto de decomposiçáo. Os resíduos que podem ser reciclados, como o plástico, papel, vidro, entre outros, devem ser encaminhados para a usina de reciclagem especializada nesses materiais. Já os resíduos da construção civil devem ser direcionados para a usina de reciclagem de RCC. Os resíduos perigosos como, por exemplo, os oriundos de construçóes e hospitais, devem ser encaminhados para aterros industriais licenciados para receber produtos desse tipo.

Logo, o município precisa implantar um aterro sanitário adequado para deposição de resíduos orgânicos e um aterro industrial que possa receber resíduos perigosos. Deve, também, incentivar a instalação de usinas de reciclagem, tanto para os resíduos de Classe A, quanto para os de Classe B, para que todo resíduo que possa passar pelo processo de reciclagem seja reciclado.

No entanto, para ser possível dar a destinação adequada a todos os tipos de resíduos, é necessário fiscalizar os geradores e coletores, sendo necessário estabelecer um órgáo que seja responsável por essa fiscalização. Além de determinar a aplicação de multas caso os geradores e coletores não cumpram a legislaçáo.

Do mesmo modo, é importante realizar açóes para conscientizar a população a fazer a correta separaçáo do lixo orgânico e reciclável, possibilitando a reciclagem desses resíduos.

Os órgãos públicos também precisam incentivar a utilização de agregados reciclados, podendo até exigir, perante lei, que a obra utilize uma porcentagem mínima deste tipo de agregado.

Ademais, as construtoras devem realizar atividades de conscientização e orientação com todos os funcionários, para instrui-los a reduzir a produção de resíduos, evitando desperdício e, posteriormente, fazer a correta separação dos resíduos produzidos. Para isso, é relevante que eles entendam a importância da reciclagem para o meio ambiente e o que a contribuiçáo de cada um deles pode fazer para mudar a atual gestáo dos RCC.

Além disso, as construtoras devem elaborar o Plano de Gerenciamento de Resíduos da Construçáo Civil (PGRCC) para cada obra, que contemple todo o conjunto de atividades realizadas a respeito dos RCC, estabelecendo os procedimentos necessários para o manejo e a destinação ambientalmente adequados.

Os PGRCC devem conter os métodos que serão realizados para caracterizar e quantificar os RCC, qual será a destinação final dada aos resíduos, respeitando a classificação, como será feita a armazenagem dos resíduos no canteiro de obras e qual o transporte adequado para cada classe de resíduo.

Ademais, as coletoras também devem se adequar obrigatoriamente as leis, e emitirem os CTR, para que seja possível ter um controle maior do que está sendo depositado nas caçambas e qual será a destinação dada aos resíduos.

A Figura 5 sintetiza as responsabilidades de cada agente atuante na gestão dos RCC, elaborada a partir da realidade encontrada em Primavera do Leste. 
Figura 5 - Responsabilidades de cada agente envolvido na gestão de RCC para Primavera do Leste-MT

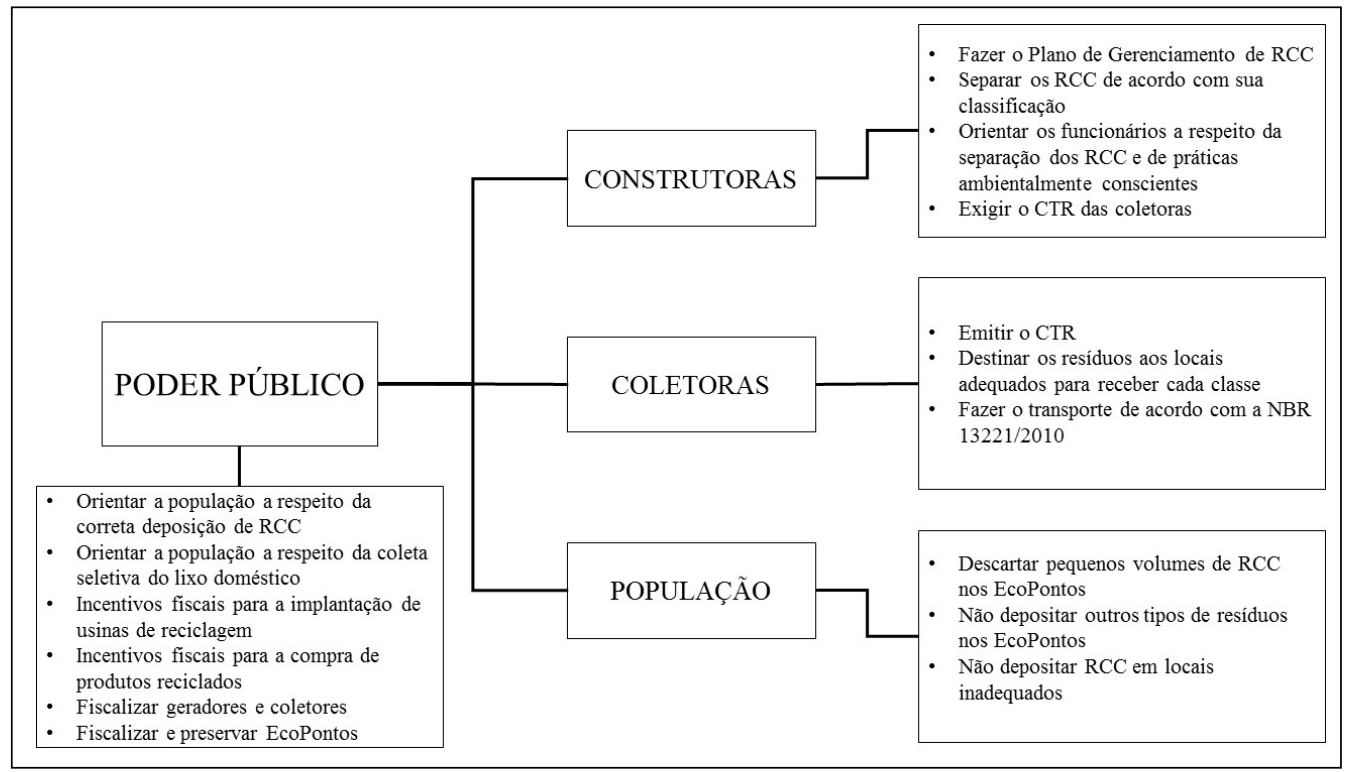

Fonte: Do autor (2017).

Os geradores de resíduos sempre devem ser incentivados pela Prefeitura Municipal, por meio de leis e de regulamentaçôes, a adotarem destinaçóes adequadas para cada tipo de resíduos, minimizando os impactos causados ao meio ambiente.

Como é possível perceber, a gestão adequada dos RCC depende de um conjunto de açóes onde todos os agentes responsáveis pela gestão devem agir de forma integrada, possibilitando assim a mudança da gestão atual.

\section{5- Conclusáo}

Diante de toda a pesquisa apresentada, verificou-se que o município de Primavera do Leste apresenta uma postura passiva no que diz respeito a gestão dos RCC. A Lei Municipal no 1420/2014, apesar de ser teoricamente eficiente, não é executada, e consequentemente a gestão atual de resíduos da construção civil não atende as exigências da Resolução CONAMA n 307/2002.

O diagnóstico apontou uma quantidade significativa de RCC gerados diariamente, cerca de 2,1 quilogramas per capita, e todo esse resíduo é descartado inadequadamente no lixão municipal, juntamente com outros tipos de resíduos, causando assim grandes impactos ao meio ambiente.

Além disso, existem diversos pontos de descarte de RCC não autorizados espalhados pela cidade, o que, além de causar poluição visual, gera danos ecológicos.

Evidente que o papel transformador mais importante é do Poder Público Municipal, que precisa criar um setor responsável pela gestão de RCC no município, que fiscalizará os 
geradores e coletores. Outrossim, será necessário conscientizar a população a respeito da importância de dar a destinaçâo correta a todos os tipos de resíduos.

Isto, somado a outras medidas, poderá minimizar os problemas ambientais causados pela deposiçáo incorreta de resíduos, visando sempre adequar a gestáo de RCC do município à Resolução CONAMA nº 307/2002.

Como proposta para estudos futuros, propóem-se analisar a viabilidade técnica e econômica para implantação de empresas de reciclagem de resíduos de Classe A e B no município, sendo necessário analisar a qualidade dos RCC gerados e quais possíveis açóes que podem assegurar a correta segregação dos resíduos pelos geradores.

\section{Referências}

ALMEIDA, R. C.. A produção do espaço urbano e as estratégias de valorização do mercado imobiliário no município de Lauro de Freitas/BA. In: SEMINÁRIO URBANISMO NA BAHIA urbBA[13], 2013, Salvador. Anais... Salvador: UFBA, 2013.

ALVES, A. Disponível em <http://www.olhardireto.com.br/agro/noticias/exibir. asp?noticia $=\% 20$ Duas_das_maiores_cidades_de_MT_perdem_espaco_no_ranking_das_ ricas\&id=12374> Acesso: 20 de janeiro de 2017.

ÂNGULO, S. C.; ZORDAN, S. E.; JOHN, V. M. Desenvolvimento sustentável e a reciclagem de resíduos na construçáo civil. São Paulo: Departamento Engenharia de Construção Civil da Escola Politécnica, 2001.

ARAÚJO, M. A. A moderna construçáo sustentável. São Paulo: Instituto para o Desenvolvimento da Habitação Ecológica, 2005.

BRASIL. Lei no 1420 de maio de 2014, Primavera do Leste-MT. Regulamenta a Lei Municipal no 1395 de 30 de outubro de 2013, delegando competências aos titulares dos órgãos da Administração Direta do Município.

BRASIL. Ministério do Meio Ambiente. Conselho Nacional do Meio Ambiente.

CONAMA. Resolução no 307, de 05 de julho de 2002. Estabelece diretrizes, critérios e procedimentos para a gestão dos resíduos da construção civil. Brasília. Publicação Diário Oficial da União, no 136, de 17 de julho de 2002, p. 95-96.

BRASIL. Ministério do Meio Ambiente. Conselho Nacional do Meio Ambiente. CONAMA. Resolução no 348, de 16 de agosto de 2004. Altera a Resolução CONAMA - 307, de 5 de julho de 2002, do Conselho Nacional do Meio Ambiente-CONAMA, incluindo o amianto na classe de resíduos perigosos. Publicação Diário Oficial da Uniáo, $\mathrm{n}^{\mathrm{o}} 158$, de 17 de agosto de 2004, p. 70.

BRASIL. Ministério do Meio Ambiente. Conselho Nacional do Meio Ambiente. CONAMA. Resolução no 431, de 24 de maio de 2011. Altera o art. $3^{\circ}$ da Resolução $\mathrm{n}^{\circ}$ 307, de 5 de julho de 2002, do Conselho Nacional do Meio Ambiente-CONAMA, 
estabelecendo nova classificação para o gesso. Publicação Diário Oficial da Uniẫo, no 99, de 25 de maio de 2011, p. 123.

BRASIL. Ministério do Meio Ambiente. Conselho Nacional do Meio Ambiente. CONAMA. Resolução no 448, de 18 de janeiro de 2012. Altera os artigos. $2^{\circ}, 4^{\circ}, 5^{\circ}, 6^{\circ}$, $8^{\circ}, 9^{\circ}, 10$ e 11 da Resolução no 307, de 5 de julho de 2002, do Conselho Nacional do Meio Ambiente-CONAMA. Publicaçáo Diário Oficial da União, no 14, de 19 de janeiro de 2012, p. 76.

BRASIL. Ministério do Meio Ambiente. Conselho Nacional do Meio Ambiente. CONAMA. Resolução no 469, de 29 de julho de 2015. Altera a Resolução CONAMA $\mathrm{n}^{\circ} 307$, de 05 de julho de 2002, que estabelece diretrizes, critérios e procedimentos para a gestão dos resíduos a construção civil. Publicação Diário Oficial da União, de 30 de julho de 2015, p. 109-110.

BRUNDTLAND, G. H. Nosso futuro comum. Comissão Mundial sobre Meio Ambiente e Desenvolvimento, 1987.

CAMARGO, A. L. de B. As dimensóes e os desafios do desenvolvimento sustentável: concepçóes, entraves e implicaçóes à sociedade humana. 2003. 198 f. Dissertação (Mestrado em Engenharia de Produção), Universidade Federal de Santa Catarina, Santa Catarina, 2003.

CARNEIRO, A. P. et al. Características do Entulho e do Agregado Reciclado. In: CASSA, J. C. S.; CARNEIRO, A. P.; BRUN, I. A. S. (Orgs.). Reciclagem de Entulhos Para a Produçáo de Materiais de Construçáo: Projeto Entulho Bom. Salvador: EDUFBA CEF, 2001.

CORRÊA, L. R. Sustentabilidade na construçáo civil. 2009.70f. Monografia (Bacharelado em Engenharia Civil) - Escola de Engenharia, Universidade Federal de Minas Gerais, Belo Horizonte, 2009.

FARIAS, A. D.; MEDEIROS, H. R. D.; FREITAS, L. S. Contribuiçóes da P+L para a gestáo de resíduos sólidos das atividades produtivas da construçáo civil. Revista Gestấo \& Sustentabilidade Ambiental, Florianópolis, v.4, n.1, p.366-391, abr/set. 2015.

FERREIRA, D. D. M.; NOSCHANG, C. R. T.; FERREIRA, L. F. Gestáo de Resíduos da Construçáo Civil e de Demoliçáa: Contribuiçóes para a Sustentabilidade Ambiental. In: CONGRESSO NACIONAL DE EXCELÊNCIA EM GESTÃO, 5., 2009, Niterói. Anais...Niterói: UFF, 2009, p. 01-23.

GARÉ, J. C.; PEREIRA, R. S. Contribuiçóes da construção civil brasileira para o desenvolvimento sustentável. In: XXXVI EnANPAD, 2012, Rio de Janeiro. Anais... Rio de Janeiro: EnANPAD, v.1, 2012, p.1-16.

IBGE - Instituto Brasileiro de Geografia e estatística. Disponível em <http://www.ibge. gov.br> Acesso: 18 de janeiro de 2017. 
KARPINSKI, L. A. et al. Gestáo diferenciada de resíduos da construçáo civil: uma abordagem ambiental. Porto Alegre: Edipucrs, 2009.

KEELER, M.; BURKE, B. Fundamentos de projeto de edificaçóes sustentáveis. Porto Alegre: Bookman, 2010.

LIBRELOTTO, L. I. Modelo para avaliaçáo da sustentabilidade na construçáo civil nas dimensóes Econômica, Social e Ambiental (ESA): Aplicação no setor de edificaçóes. São Paulo: Edgard Blucher, 2008.

MAGNI, L. C. Levantamento e análise da deposiçáo e destinação dos resíduos da construçáo civil em Barra do Garças-MT. 2014. 40f. Monografia (Bacharelado em Engenharia Civil), Universidade Federal de Mato Grosso, Barra do Garças, 2014.

NAGALLI, A. Gerenciamento de resíduos sólidos na construção civil. São Paulo: Oficina de Textos, 2014.

PRIMAVERA DO LESTE. Lei no 1420 de maio de 2014. Regulamenta a Lei Municipal no 1395 de 30 de outubro de 2013, delegando competências aos titulares dos órgãos da Administração Direta do Município.

RIGOLON, F. J. Z. A retomada do crescimento e o papel do BNDES. Rio de Janeiro: BNDES, 1996.

SEABRA, L. O., TACO, P. W. G., e DOMINGUEZ, E. M. Sustentabilidade em transportes: do conceito às políticas públicas de mobilidade urbana. Revista dos Transportes Públicos - ANTP, 2013. Disponível em: <http://www.academia. edu/4785172/Sustentabilidade_em_transportes_do_conceito_\%C3\%A0s_

pol\%C3\%ADticas_p\%C3\%BAblicas_de_mobilidade_urbana>. Acesso: 10 de dezembro de 2018 .

SILVA, E. L. S.; MENEZES, E. M. Metodologia da pesquisa e elaboraçáo de dissertaçáo. 4 ed. Florianópolis: UFSC, 2005.

TEIXEIRA, L. P.; CARVALHO, F. M. A. de. A construção civil como instrumento do desenvolvimento da economia brasileira. Revista Paranaense de Desenvolvimento, Curitiba, n. 109, p. 09-26, jul/dez. 2005.

TOCHA, R. Sustentabilidade na construção civil. Disponível em <http://

certificacaoiso.com.br/sustentabilidade-na-construcao-civil-com-pbqp-h/> Acesso: $02 \mathrm{de}$ março de 2017.

TOMAZELE, I. Estudo sobre o gerenciamento dos resíduos da construçáo civil na cidade de Rondonópolis-MT. 2015. 56f. Monografia (Bacharelado em Engenharia Civil), Universidade Federal de Mato Grosso, Barra do Garças, 2015.

VEIGA, J. E. da. Desenvolvimento sustentável: o desafio do século XXI. 3. ed. Rio de Janeiro: Garamond, 2008. 